\title{
RELIGIOSITY AND RETAIL STORE CHOICES: EXPLORING US CHRISTIAN CONSUMERS' APPAREL SHOPPING BEHAVIOR
}

\author{
LIZHU DAVIS \\ CALIFornia STATE UniVERsity Fresno, USA
}

\begin{abstract}
Although religion is a key component of culture that affects a society's value system and human behavior, few have investigated how religion and religiosity influence consumers' patronage and apparel shopping behavior. This study investigated the impact of religiosity on U.S. Christian consumers' perceived importance of apparel store attributes. The findings reveal that among commonly used consumer demographics included in the study, religiosity is the most powerful factor affecting the importance of different apparel store attributes. The findings suggest that more committed U.S. Christians are more involved and demanding fashion consumers. Companies that ignore the influence of religion and religiosity in the retail market might find themselves suffering.
\end{abstract}

\section{Introduction}

Understanding consumers' patronage behavior is vital for a successful retail business (Sirgy, Grewal, \& Mangleburg, 2000), especially in an increasingly competitive and globalized retail market. However, many factors affect consumers' patronage behavior, one of which is culture. Scholars (e.g. Chang \& Chuang, 2005; Shaw \& Clarke, 1998) argue that culture is a main external factor that shapes an individual's consumption and shopping behavior. As a key component of culture, religion not only moralistically sets up values, beliefs, and practice requirements for believers (Worthington et al., 2003) but also provides a basis for the socialization of values (Kahle, Kau, Tambyah, Tan, \& Jung, 2005). Religious values affect believers' moral standards, personal and social values, as well as cognition and psychological well-being which in turn affect their consumption and shopping behavior in the marketplace. 
Consumers may consume or reject certain products and/or brands to demonstrate their religious identity (Lindridge, 2005; Schroeder, 2000). Sheth's (1981) integrative theory of retail store patronage preference and behavior also suggests that religion is an important consumer value and it may affect consumers' shopping motivation. Overall, religion correlates with different attitudinal and behavior variables that affect consumer behavior (Wilkes, Burnett, \& Howell, 1986).

The knowledge of how religion affects consumers' consumption decision making processes and shopping behavior may significantly influence the effectiveness of global marketing strategies, especially the usage of appropriate communication tools and tactics (Delener, 1994) and retail branding. However, this topic has been largely ignored by marketing and consumer behavior researchers. Until recently, limited studies on this topic have been published in research journals. So, more research is needed to investigate the impact of religion on retail patronage and shopping behavior (Moschis \& Ong, 2011; Swimberghe, Sharma \& Flurry, 2009). Meanwhile, since the late 1990s, most consumer behavior research on religiosity was conducted in non-Christian countries such as Thailand and Malaysia, and little was done in the United States. However, the United States is a highly religious country with $76 \%$ of U.S. adults being Christians (U.S. Census, 2012). Within the broader Christian market, there is a rapid growing segment: faith driven consumers (The Stone Agency, 2012). This segment includes more than 46 million Americans with $\$ 1.75$ trillion in annual spending power. Based on annual spending power, this market is nearly twice the size of the African American market and three times the size of the Asian American market (Faithnomics, 2012). According to Chris Stone, a brand strategist and founding partner of The Stone Agency, these faith driven consumers actively seek companies and brands that respect Christian beliefs and values. They are willing to switch to those companies and brands even if they have to pay more money (The Stone Agency, 2012). Meanwhile, highly religious consumers not only morally judge companies that support controversial causes that are contrary to their religious values, but also express their dissatisfaction through protest and boycott (Swimberghe, Flurry \& Park, 2011).

Furthermore, with the change of popular culture in the United States, religion has become a more controversial topic even in the business world. Some companies, such as Hobby Lobby and Chick-fil-A that advocate Christian values have become the center of debate. Chick-fil-A, for example, saw a tremendous protest after announcing its opposition to gay marriage in 2012; however, the sales of the restaurant chain spiked at the same time from consumers who supported the brand's stands. This case 
clearly demonstrates the importance of reviewing the role of religion and religious values in the consumer market. So, to be competitive in today's U.S. retail market, retailers may want to pay more attention to the relationship between religion and consumer behavior and investigate how religion and faith affect consumers' shopping and patronage behavior. Companies that ignore the role of religion in the consumer market may find themselves suffering.

Store attributes, defined as evaluative criteria consumers have toward the store (Jin \& Kim, 2003), significantly affect store image and consumers' retail patronage behavior. Literature reveals that store attributes relate to time spent in a retail store (Donovan, Rossiter, Marcoolyn \& Nesdale, 1994), help to create positive consumer response, influence store choices (Bender, 1964), and even impact purchase decisions inside a store (Sherman, Mathur \& Smith, 1997). Depending on shopping context and product category, consumers desire different store attributes. Furthermore, shopping orientation (Lumpkin, 1985; Shim \& Kotsiopulos, 1992), information sources (Shim \& Kotsiopulos, 1992), personal characteristics including age, gender, education level and income (Seock \& Sauls, 2008), as well as consumer value (Erdem, Oumlil, \& Tuncalp, 1999) and culture values (Seock \& Lin, 2011) all affect consumer perceived importance of store attributes. Consumers with certain values are likely to prefer different store attributes than others (Erdem et al., 1999; Seock \& Lin, 2011). As an important consumer value (Sheth, 1981), religion may also affect consumers' preferences of different store attributes.

Consumer behavior research on religion has two major focuses: religious affiliation and religious commitment. Religious commitment is commonly termed as religiosity in marketing literature. Specifically, religiosity refers to the extent to which an individual is committed to the religion he or she professes and its teachings. It extends beyond the concept of religious affiliation. It is the degree to which beliefs in specific religious values and ideals are held and practised by an individual (Swinyard, Kau, \& Phua, 2001). Although some studies found that religious affiliation significantly affected some aspects of consumer behavior such as purchase decisions (Hirschman, 1981), many researchers (Essoo \& Dibb, 2004; McDaniel \& Burnett, 1990) argue that religiosity is a stronger affecting factor than religious affiliation. Therefore, the purpose of this study was to investigate the effect of religiosity on U.S. consumers' perceived importance of store attributes when they shop for apparel. The findings of the study provide valuable information to fashion retailers to 
better serve their consumers, especially those in regions and cities where religion is an important part of their lives.

\section{Literature Review}

\section{Religiosity and Consumer Behavior}

It is commonly accepted that religiosity is a multi-dimensional concept. From the motivational perspective, religiosity can be defined as extrinsic and intrinsic religiosity. Intrinsically and extrinsically oriented people follow religions in quite different ways. Extrinsically orientated people follow the religion from the utilitarian point of view; that is, they adopt religious teaching selectively to suit specific purposes such as to cope with difficult life events and situations (Allport \& Ross, 1967). However, intrinsic religiousness describes religious belief as the basis of life. That is, for intrinsically orientated people, pursuing religion is the prime goal of their lives. They tend to fully integrate religious teachings and values into their lives, and adhere to religious teachings at all times (Allport \& Ross, 1967). Religiosity can also be classified as intrapersonal and interpersonal religiosity (McDaniel \& Burnett, 1990). Intrapersonal religiosity is largely cognitive that focusses on personal religious beliefs and experiences. It is about internalization of religious values and experiences. Interpersonal religiosity, on the other hand, is the behavioral component which focusses on the level of activities in organized religion (McDaniel \& Burnett, 1990).

Religiosity is important for consumer behavior studies because it is related to consumer behavior variables including lifestyle and retail patronage behavior. The value systems of religious people are different from those of less religious people or non-religious people (Mokhlis, 2006). A highly committed person may evaluate the world through their religious view, thus integrating his or her life with religious values and teachings (Worthington, 1988). Those who have strong faith in their religion tend to hold strong social values and are more susceptive to normative influences from frequent interaction with fellow believers (Alam, Mohd \& Hisham, 2011). Thus, they tend to follow religious principles and values for their daily activities. Generally, highly religious people tend to "behave in a relatively mature, disciplined and responsible manner" (Alam et al., 2011, p. 93). They tend to have greater concerns for moral standards (Wiebe \& Fleck, 1980) and more traditional views (Wilkes, Buurnett, \& Howell, 1986), as well as to be more conservative (Barton \& Vanghan, 1976) and satisfied with their lives (Wilkes et al., 1986) than less religious people. They are committed to many aspects of 
their lives, including family, relationships, and certain consumption behavior (Mokhlis, 2006).

Researchers have studied the effects of religiosity on several aspects of consumer behavior, including information seeking (Choi, Kale \& Shin, 2010), consumer attitudes (Fam, Waller, \& Erdogan, 2004; Vitell \& Paolillo, 2003), shopping orientation (Davis \& Jai, 2014; Essoo \& Dibb, 2004), and store choice criteria (e.g. McDaniel \& Burnett, 1990). Choi et al (2010) studied the impact of religiosity on consumers' usage of different information sources which include significant others, members of the same religious group, media advertisement, impartial sources, and salespeople. The findings suggest that religiosity affects Korean consumers' usage of product information sources. Religious Korean consumers are more likely to seek information from others in the same religious group, but less likely to trust external sources including media and salespeople (Choi et al., 2010). The study concluded that the conservative nature of religions contributes to highly religious consumers being less receptive to external information sources. Fam et al. (2004) studied the influence of religiosity on consumers' attitudes towards advising controversial products. The controversial products included in the study were gender/sex related products such as female hygiene products, social/political groups such as political parties, addictive products such as alcohol, as well as health and care products such as weight-loss programs. The findings reveal that more religiously committed respondents were more likely to find advertising of gender/sex related products, health and care products, and addictive products offensive than less devoted ones (Fam et al., 2004). Therefore, religiosity affects consumers' attitudes towards advertising controversial products.

Religiosity also affects consumers shopping orientation, that is, consumers' general beliefs, feelings, and actions toward shopping. However, findings of existing studies are somewhat inconsistent with each other. Using the scenario of purchasing a relatively expensive home radio, Sood and Nasu (1995) found that more religious U.S. Protestants were more economically oriented, that is, they were more likely to purchase products when they are on sale but not when they needed, and preferred stores having lower prices. They also believed there is little relationship between price and quality (Sood \& Nasu, 1995). Based on consumer decision-making style, Mokhlis (2006) found that religious Malaysian consumers tended to look for high quality merchandise when shopping for apparel. Using the scenario of purchasing a television set, Essoo and Dibb (2004) found, however, casual religious respondents emphasized more on the importance of deals, promotions, product and service quality, brand 
name, as well as in-store credit. In another study, Davis and Jai (2014) found that more committed U.S. Christians were more fashion, quality and price oriented when it comes to shopping for apparel; but they did not emphasize brand name, nor were they brand-loyal. Shachar et al. (2011), furthermore, conducted a series of studies on the relationship between religiosity and consumers' choices of name brand merchandise over nonbrand or store brand merchandise. Findings of their studies (2011) concluded that for socially expressive goods such as apparel, religiosity negatively affected consumers' choice of name brands. That is, when it comes to socially expressive goods such as apparel, more religious people are less likely to use branded merchandise for self-expression, especially the expression of self-worth.

To summarize, existing studies provide sound evidence that religiosity significantly affects consumer behavior. Consumers' shopping behavior can be categorized according to their levels of religiosity, that is, how committed they are to their faith (Essoo \& Dibb, 2004; King \& Crowther, 2004). So, to fully understand consumer behavior in depth, we should not overlook the importance of religion and religiosity in consumer lifestyle and consumption behavior. However, limited studies cannot provide sufficient explanations on how religiosity affects different consumer behavior such as consumers' patronage behaviors because they differ by shopping scenario and product category.

\section{Religiosity and Store Attributes}

Store attributes are presented by retailers according to their specific functional strategies. To be competitive, retailers have to offer specific store attributes that their target consumers desire. Belk (1988) argues that although physical attributes and functional criteria of a store are very important for consumers when they decide where to shop, the congruity between the consumer identity and store identity is also critical. What consumers purchase and where they shop reflected their extended selves (Belk, 1988). Therefore, consumers tend to shop at stores that they can identify with. Supporting Belk's (1988) arguments, Swimberghe et al. (2009) found that highly religious consumers are more likely to visit a store that is consistent to their religious beliefs and values. They also use it as a non-functional criterion to determine whether they should be loyal to a store or not. Since religious beliefs and values are an intricate part of highly religious consumers' identity and self-concept, they are more likely to shop at, and be loyal to stores that are compliant to their religious values (Swimberghe et al, 2009). 
Few studies investigated how religiosity affects consumers' store choice criteria and their perceived importance of different store attributes. McDaniel and Burnett (1990) found that varying dimensions of religiosity affect consumer perceived importance of store attributes differently. Although sales personnel friendliness/assistance was very important for respondents that were high at either intrapersonal or interpersonal religiosity, those with high intrapersonal religiosity emphasized more on shopping effectiveness and product quality when selecting a department store, while those with high interpersonal religiosity valued shopping convenience more (McKaniel \& Burnett, 1990). Mokhlis (2008) found religious Malaysian consumers placed a higher level of importance on merchandise related attributes including quality, brand, price and selection and reputation of the store, but less importance on attractiveness of the store than less religious consumers. Khraim et al. (2011), on the other hand, found that more religious Jordanians considered all store attributes evaluated more important than less religious consumers; that is, they placed a greater importance on merchandise criteria (price, variety and availability), service quality (in-store and post-purchase), visual display, location, and kinship. All the studies above reveal that consumer religiosity significantly affects consumers' perceived importance of different store attributes. Therefore, it is hypothesized that religiosity significantly affects U.S. Christian consumers' perceived importance of store attributes when they shop for apparel.

Hypothesis: Religiosity significantly affects U.S. Christian consumers' perceived importance of store attributes when they shop for apparel.

\section{Methodology}

An online survey was developed to measure consumers' religiosity, apparel store attributes, and respondents' demographic characteristics including age, gender, education level, annual household income, and religious affiliation. For the purpose of this study, the Religious Commitment Inventory, RCI-10 (Worthington et al., 2003) was adopted to measure religiosity using a 5-point Likert-type scale from 1 (strongly disagree) to 5 (strongly agree). This scale was designed to assess the degree to which a person commits to his or her religious values, beliefs, and practices and uses of them in daily living (Shachar et al., 2011). It has been widely used in the marketing research because it was reliable $(\alpha=0.95)$ and demonstrated strong validity with other religiosity measurements (Worthington et al., 2003). Meanwhile, 27 items measuring salient apparel store attributes from consumer patronage literature (Erdem et al., 1999; 
Paulins \& Geisteld, 2003; Seock \& Sauls, 2008) were adopted. A 5-point Likert-type scale from 1 (not important at all) to 5 (very important) was used to measure responses to those scale items.

Undergraduate students from two fashion merchandising classes of a major state university in the southwestern United States were instructed to recruit potential participants using social media such as Facebook over a two-month period. A total of 568 finished questionnaires were collected, resulting in 333 usable responses composed of Christian respondents for this study. Among the respondents, $82.2 \%$ were female. Hispanics and Caucasian whites were two major ethnic groups, accounting for $37.2 \%$ and $33.8 \%$ of respondents respectively. The majority of the respondents, more than $90 \%$, have some college or a college degree; and $46.4 \%$ of respondents were age 18-24. Overall, the sample characteristics reflected the college student population of the university community in the southwestern United States. More detailed demographic characteristic information is provided in Table 1.

\section{Analysis and Results}

A factor analysis was first conducted using principal axis factoring to identify underlying factors of religiosity and store attributes. Factors with eigenvalues greater than 1.0 and factor loadings of .50 were used as the criteria for retaining items (Hair, Black, Babin, \& Anderson, 2010). To ensure that each factor would have one dimension, any item loading on more than one factor with a loading score equal or greater than 0.40 on each factor was eliminated. The principle axis factoring analysis with a Promax rotation with Kaiser Normalization revealed only one underlying factor for religiosity. The scale is highly reliable with a Cronbach's Alpha equals to .96 . Because all the items had a high factor loading (>.8), all the items of the scale were kept for further analysis. Meanwhile, the principle axis factoring analysis revealed four factors with an eigenvalue of one or greater for store attributes. These four factors accumulatively explained $64 \%$ of variance (see Table 2).

Four factors of store attributes revealed were labeled: 1) merchandise and convenience, 2) shopping environment, 3) fashion reputation, 4) social status. Six items that had no significant loadings on any of the factors above (factor loading less than .50) were eliminated for testing hypothesis because omitting the problematic items (e.g., variable with no significant loadings or with a cross-loading) is appropriate if the objective is data reduction (Hair et al., 2010). The finalized four factors were then used in the following analysis to examine the effect of religiosity on consumer 
perceived importance of different apparel store attributes. The reliability test results indicate that all scales are reliable with Cronbach's Alpha values larger than .50. Please see Table 3 for the summary of items and factor loadings for Promax rotation of store attributes.

Table 1 Characteristics of Respondents $(\mathrm{N}=333)$

\begin{tabular}{|l|l|c|}
\hline Characteristics & Male & Percentage \\
\hline Gender & Female & 17.8 \\
& Missing & 82.2 \\
\hline Age & $18-24$ & .3 \\
& $25-34$ & 46.4 \\
& $35-44$ & 25.0 \\
& $45-54$ & 8.1 \\
& 55 and older & 11.7 \\
\hline Ethnic Group & African American & 8.7 \\
\hline & Asian or Pacific & 7.9 \\
& Islander & 13.3 \\
& Caucasian & 33.8 \\
& Hispanic American & 37.2 \\
& Native American & .9 \\
& Others & 6.9 \\
\hline Education & High school graduate & 9.4 \\
& Some College & 39.3 \\
& 2 Year College Degree & 10.3 \\
& 4 Year College Degree & 25.1 \\
& Graduate Degree & 14.5 \\
& Others & 1.5 \\
\hline Household Income & Less than \$25,000 & 35.6 \\
& \$25,000-\$50,000 & 22.2 \\
& \$50,001-\$75,000 & 11.2 \\
& \$75,001-\$100,000 & 14.3 \\
& More than \$100,000 & 16.7 \\
\hline
\end{tabular}




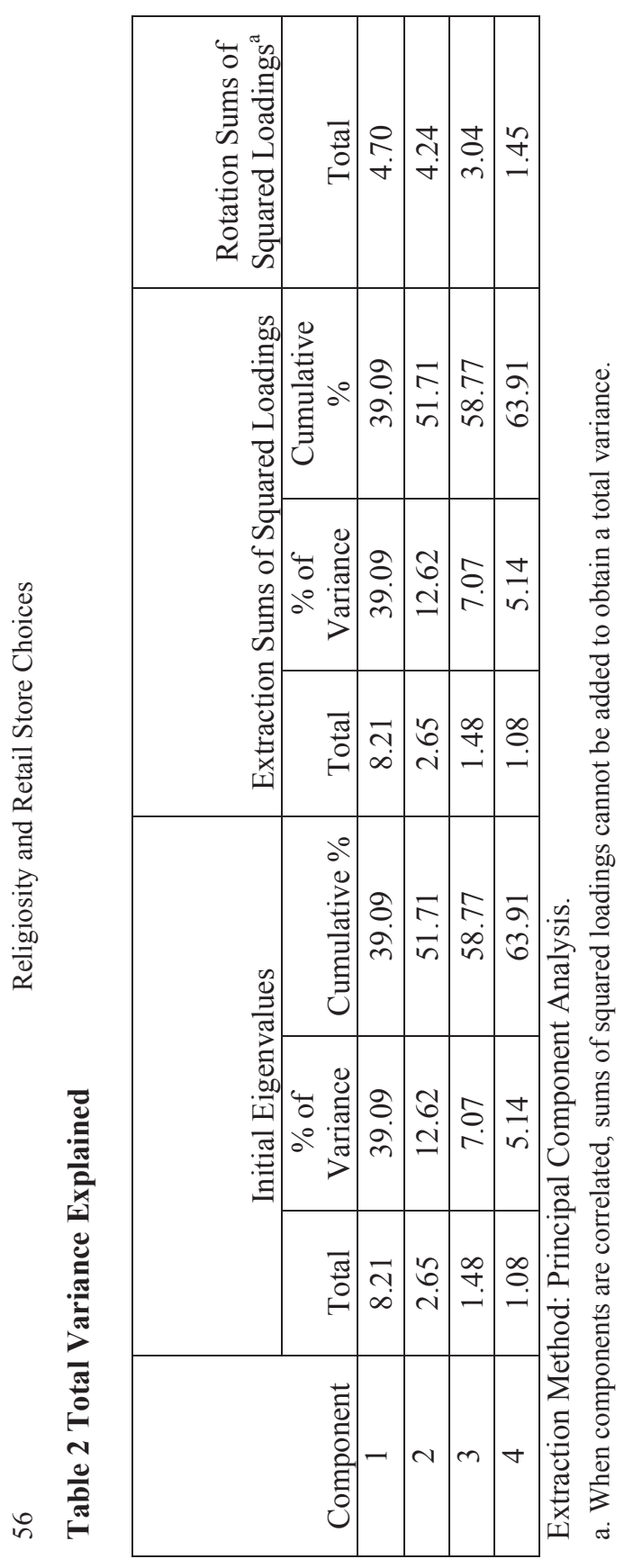


A multivariate analysis (MANOVA) and univariate analysis (ANOVA) were used to test the hypothesis. Since some demographics (e.g. Seock \& Sauls, 2008) significantly affect consumers' perceived importance of store attributes, key demographic variables including age, gender, annual household income, and education level were used as control variables. Using Wilks' Lambda test (see Table 4), MANOVA results reveal that among all the independent variables, age $(\mathrm{p}=0.032)$, education level $(\mathrm{p}=0.024)$, and religiosity $(\mathrm{p}=0.014)$ significantly affect participants' perceived importance of store attributes when they shop for apparel; but neither gender $(p=0.159)$ nor annual household income $(p=0.169)$ significantly affect participants' perceived importance of store attributes in this case. However, the value of Partial Estimated Squared reveal that compared with age (Partial Eta Squared=0.024) and education level (Partial Eta Squared=0.029), religiosity (Partial Eta Squared=0.043) is the strongest variable that affecting participants' perceived importance of apparel store attributes.

The ANOVA results (see Table 5) reveal that religiosity significantly affects participants' perceived importance of all four apparel store attributes. The R-square value for each model is .074, .101, .120, and .106 respectively. The parameter estimates (see Table 6) indicate that religiosity has a positive relationship with all the store attributes that were studied in this study after controlling age, gender, education levels, and annual household income. The results indicate that more committed Christian consumers emphasize more on all the store attributes investigated when they shop for apparel. Thus the hypothesis is supported. 


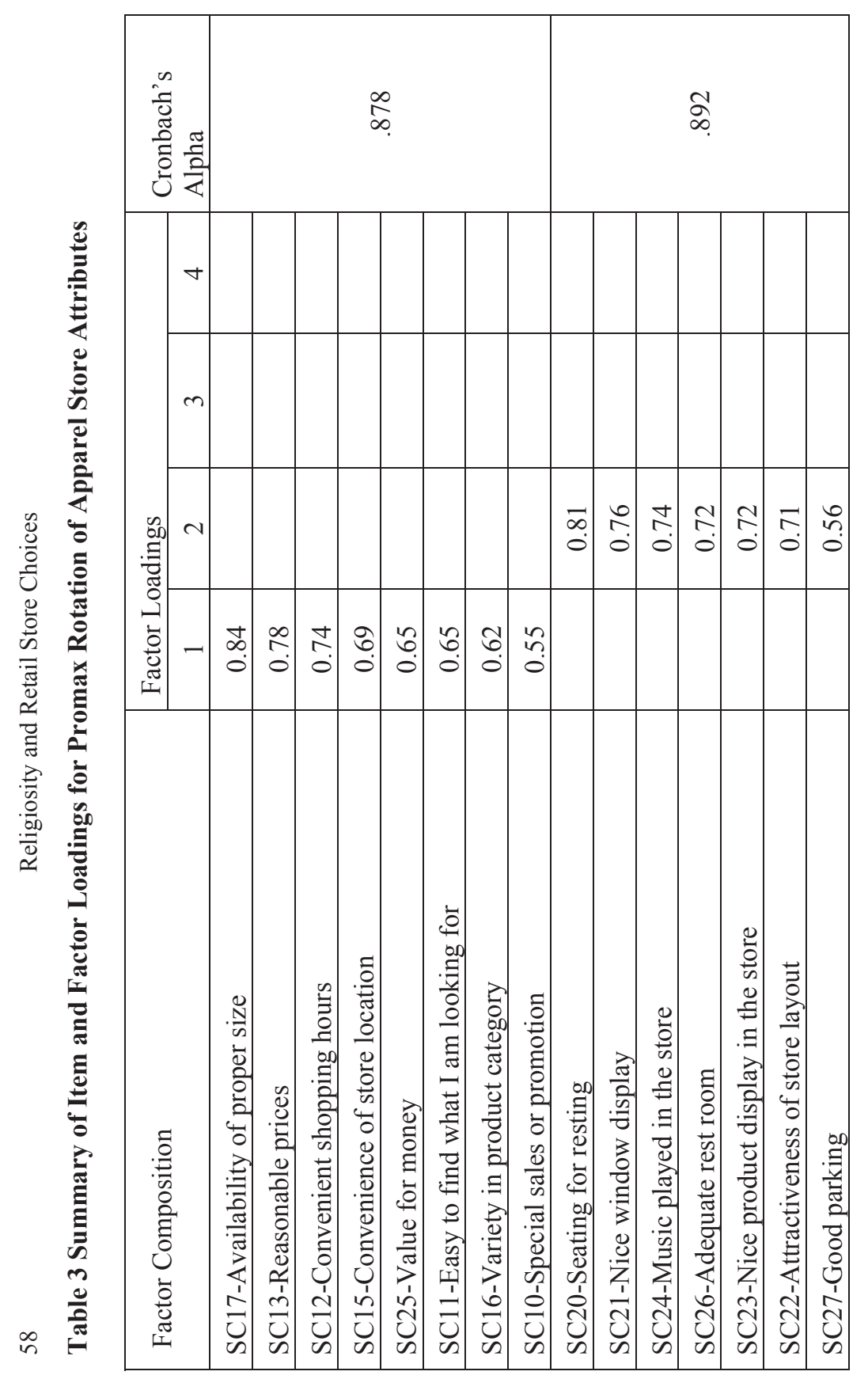



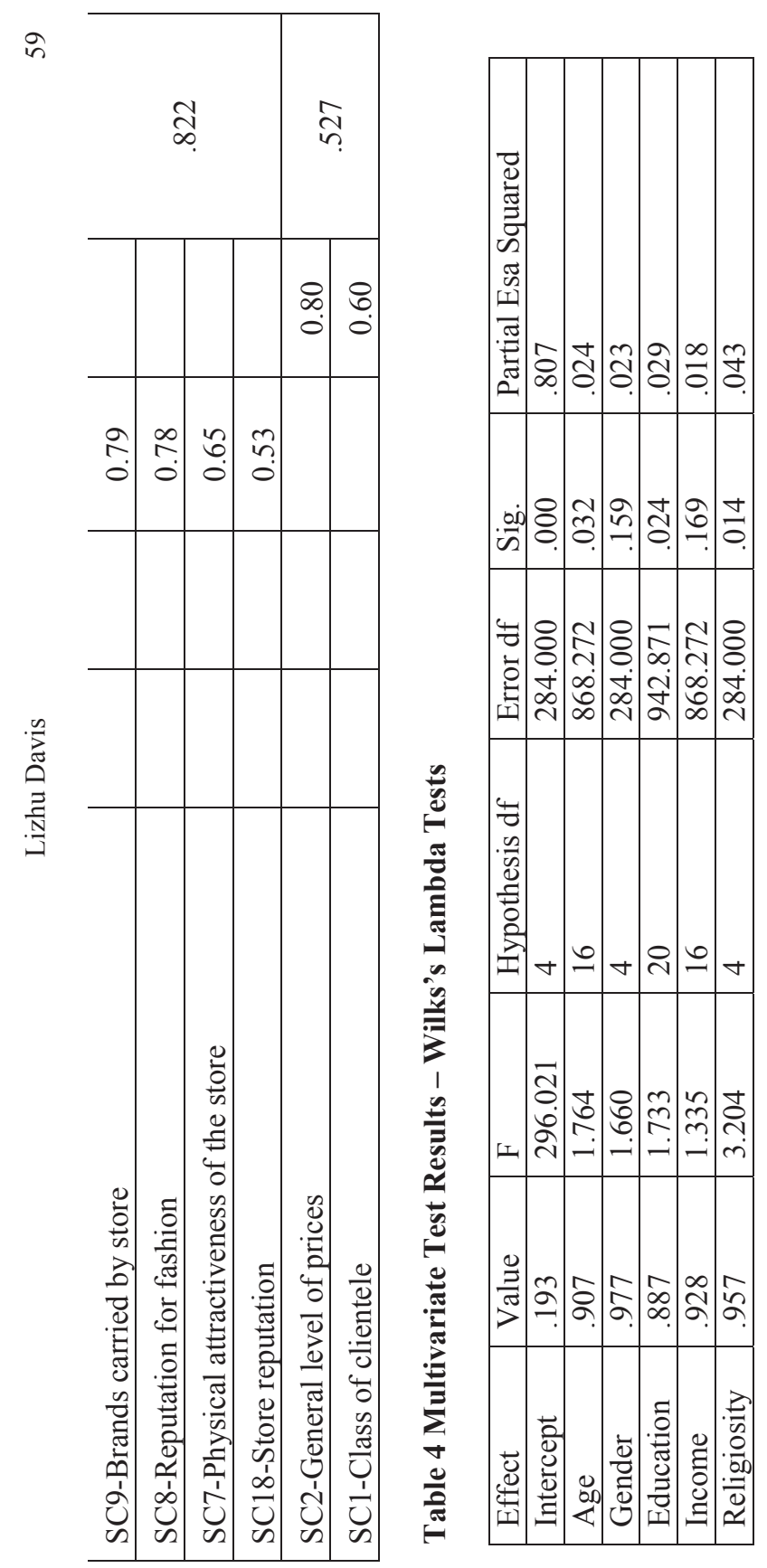


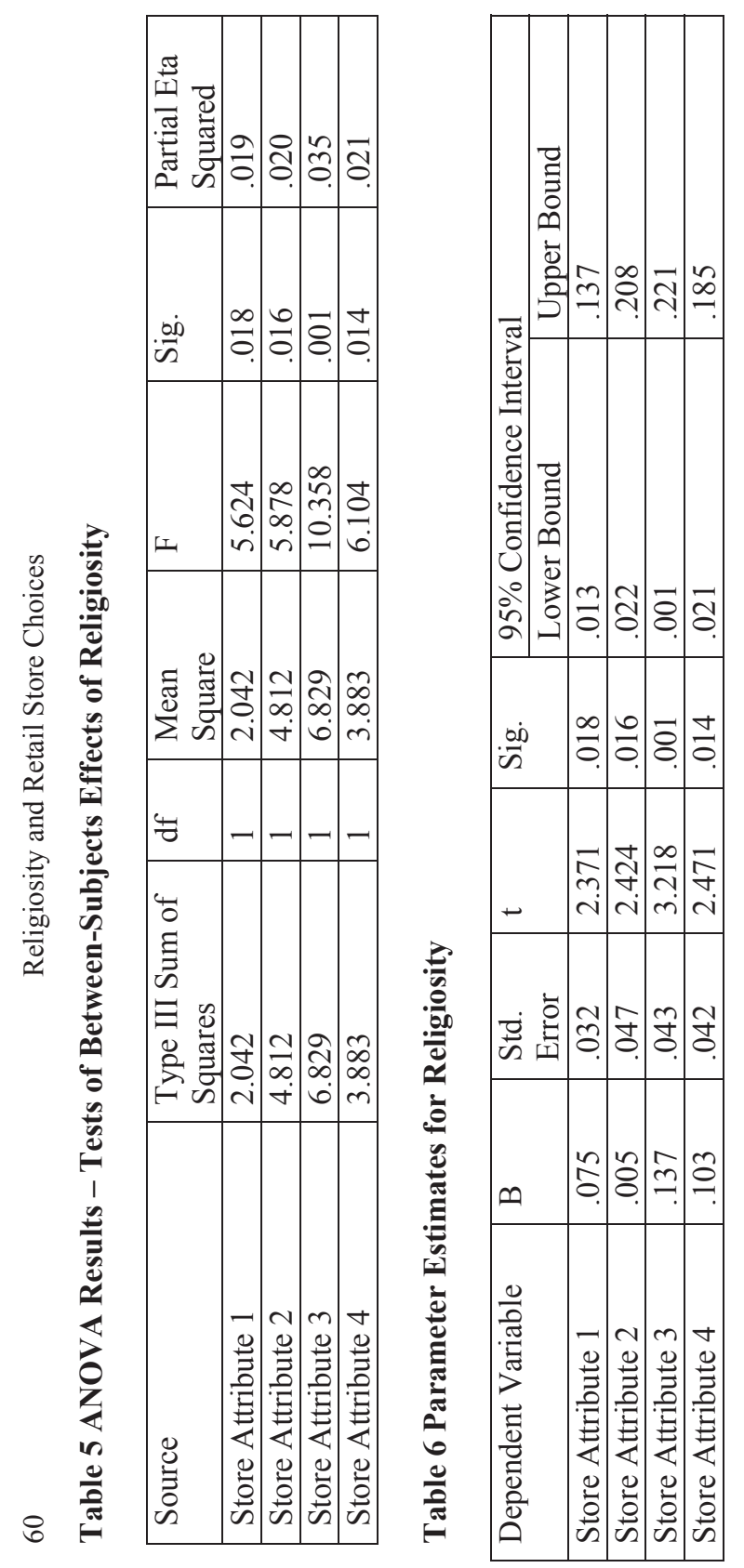




\section{Discussions and Conclusions}

As a key element of culture, religion not only provides the framework for consumers' social and personal values, but also lays the foundation for their social identity and guides them to make value-based choices (Kahle et al., 2005). Religion, especially religiosity, also significantly impacts consumers' behavior in the marketplace (Bailey \& Sood, 1993; Hirschman, 1981; Sheth, 1981). However, few studies have investigated the effect of religiosity on consumers' patronage and shopping behavior. Therefore, this study aimed to examine the relationship between religiosity and U.S. Christian consumers' perceived importance of store attributes when they shop for apparel.

The findings of this study reveal that religiosity significantly affects U.S. Christian consumers' perceived importance of store attributes. Similar to religious Malaysian consumers (Mokhlis, 2008) and Jordanian Muslim consumers (Khraim et al., 2011), more committed U.S. Christians put more importance on merchandise criteria including size, price and promotion, as well as assortment. They paid more attention to merchandise related store attributes because more religious people are more conservative (Mokhlis, 2008). Also, similar to religious Muslim consumers in Jordan (Khraim et al., 2011), more committed U.S. Christian consumers emphasized more on shopping convenience including store location and operating hours. These findings imply that more committed U.S. Christians are very likely to be functional shoppers who like to have the shopping task done efficiently; therefore, they highly value utilitarian aspects of store attributes. However, unlike religious Malaysian consumers, who emphasized less on store attractiveness when shopping for apparel (Mokhlis, 2008), this study reveals that more committed U.S. Christians demanded pleasant shopping environment. Furthermore, Davis and Jai (2014) found that devout U.S. Christians are more fashion oriented, that is, latest fashions and trends of apparel are very important for those consumers. Consistent with their findings (2014), this study reveals that more committed U.S. Christians believed that fashion reputation and brands a retailer carries is a very important store attribute. Literature reveals that more religious people have a tendency of seeking security and avoiding uncertainty (Schwartz \& Huismans, 1995). This value orientation of religious people in general may also help to explain why more committed U.S. Christians attach higher importance to fashion brands because brand name tends to guarantee consistent values that consumers look for. Also, they may be loyal to brands that respect Christian values and worldviews. Finally, similar to religious Malaysian consumers 
(Mokhlis, 2008), this study reveals that more committed U.S. Christians also put a higher importance on social status of stores. To conclude, more committed U.S. Christian consumers place higher levels of importance on all store attributes that were investigated in this study.

Overall, the findings of the study suggest that more committed U.S. Christians are more involved and demanding apparel consumers than less committed ones. They emphasize both hedonic (e.g. shopping environment and store social status) and utilitarian (e.g. merchandise and convenience) aspects of store attributes. Supporting Mokhlis' argument (2006), the findings of this study imply that more committed U.S. Christian consumers are more committed to apparel shopping. Therefore, religiosity might be an effective consumer variable for fashion retailers to segment their market in order to develop successful marketing and merchandising strategies. In fact, the findings of this study reveal that compared with key consumer demographic variables including age, gender, education level, and annual household income religiosity is the most powerful affecting factor on consumers' perceived importance of apparel store attributes. The commonly used consumer demographic variables for market segmentation may be insufficient for understanding consumer patronage behavior. So, findings of this study highlight the importance of including religion and religiosity in consumer behavior and marketing research. To be more competitive, it is critical for fashion retailers, especially those located in the areas with a high concentration of devout Christians to understand the role of consumer religiosity on their patronage behavior.

Furthermore, because of the large spending power of newly emerged faith driven Christian consumers, $\$ 1.75$ trillion annually (Faithnomics, 2012), some fashion retailers might want to target more committed U.S. Christians. To be successful in this segment of the market, retailers have to provide right merchandise mix focusing on style, size, assortment and fashion brands, as well as reasonable prices and appealing promotions. They also need to create a pleasant shopping environment using effective visual merchandising strategies including interior design, product and window display, as well as atmospherics. Furthermore, they want to be very strategic when it comes to choosing locations and deciding on operating hours to offer shopping convenience. Finally, their marketing strategies should focus on creating an appealing fashion image. Above all, these retailers need to focus more on traditional social values and avoid taking stands on sensitive political and social issues. When reconsidering their strategies, they need to examine the role of religion and religiosity in the consumer market. Only those that can capture the evolvement of 
consumers and market trends and are able to be relevant to their target consumers can be the true winners in a competitive retail market.

\section{Limitations and Future Studies}

This study has several limitations. The first one is about conceptualization and measurement issues. Religiosity itself may not be the most effective and efficient measurement for studies on religion and consumer behavior (Muhamad \& Mizerski, 2010). Other measurements such as religious motivation, which is the most established construct measuring religion and human behavior (Donahue, 1985), should be explored in the future. Meanwhile, there have been very limited efforts on the conceptualization of religious influence in the marketplace (Muhamad $\&$ Mizerski, 2010). Concepts that directly reflect the effect of religion and religiosity on consumer attitudes and/or behaviors in the marketplace might offer better understanding on how religion impacts consumer behavior. Therefore, future research might also want to focus on conceptualization of religious influence in the marketplace. The second limitation is not including other variables. Swimberghe et al. (2011) found that Christian conservative values significantly affect consumers' forming of ethical judgment on retailers and subsequent marketplace behaviors; they argued that conservatism might be a necessary variable when evaluating the influence of religion in the marketplace. Some researchers also argue that variables such as nationality and ethnicity are more effective consumer variables than religiosity. For example, Sood and Nasu (1995) found that while there was no significant difference between devout and casual religious Japanese consumers regarding shopping behavior investigated, there was significant difference between devout and casual U.S. Protestant Christians. This study also demonstrated that although there are some similarities between committed U.S. Christians and religious consumers in other countries such as Malaysian, there are also some differences. Therefore, future studies might want to consider other variables such as religious values and key cultural variables. Those variables along with the religiosity might provide more accurate information and insights. The last limitation is the sampling method. A convenient sample with a large percentage of young people was used in this study. A future study with a random sample is also recommended. 


\section{References}

Alam, S.S., Mohd, R. \& Hisham, B. (2011). 'Is religiosity an important determinant on Muslim consumer behavior in Malaysia?' Journal of Islamic Marketing 2 (1), pp. 83-96.

Allport, G.W. \& Ross, J.M. (1967). 'Personal religious orientation and prejudice.' Journal of Personality and Social Psychology 5(4), 432443.

Bailey, J.M. \& Sood, J. (1993). 'The effects of religious affiliation on consumer behavior: a preliminary investigation.' Journal of Managerial Issues 5(3), pp. 328-352.

Barton, K. \& Vaughan, G.M. (1976). 'Church membership and personality: A longitudinal study.' Social Behavior and Personality: An International Journal 4(1), pp. 11-16.

Belk, R.W. (1988).' Possessions and the extended self.' Journal of Consumer Research 15(2), pp. 139-168.

Bender, W. C. (1964). 'Consumer purchase-costs-do retailers recognize them?' Journal of Retailing 40(1), pp. 1-52.

Chang, L. C. \& Chuang, H. (2005). 'The study of subculture and consumer behavior: an example of Taiwanese university students' consumption culture.' Journal of American Academy of Business 7(2), pp. 258-264.

Choi, Y., Kale, R. \& Shin, J. (2010). 'Religiosity and consumers' use of product information source among Korean consumers: An exploratory research.' International Journal of Consumer Studies 34(1),pp. 61-68.

Davis, Y. \& Jai, C. (2014). 'Effects of religiosity on apparel shopping orientation: An exploratory study.' International Journal of Business Anthropology 5(2), pp. 24-36.

Delener, N. (1994). 'Religious contrasts in consumer decision behavior patterns: their dimensions and marketing implications.' European Journal of Marketing 28(5), pp. 36-53.

Donovan, R.J., Rossiter, J.R., Marcoolyn, G. \& Nesdale, A. (1994). 'Store atmosphere and purchasing behavior.' Journal of Retailing 70(3), pp. 283-294.

Donahue, M.J. (1985). 'Intrinsic and extrinsic religiousness: The empirical research.' Journal for the Scientific Study of Religion 24(4),pp. 418423.

Essoo, N. \& Dibb, S. (2004). 'Religious influences on shopping behavior: An exploratory study.' Journal of Marketing Management 20(7/8), pp. 683-612. 
Erdem, O., Oumlil, A.B. \& Tuncalp S. (1999). 'Consumer values and the importance of store attributes.' International Journal of Retail and Distribution Management 27(4), pp. 137-144.

Faithnomics (2012).'Targeting the $\$ 1.75$ trillion faith driven consumer market.' Retrieved July 26, 2013 from http:/www.faithnomics.com/2012/04/26/targeting-the-1-75-trillionfaith-driven-consumer-market/.

Fam, K.S., Waller, D.S. \& Erdogan, B. Z. (2004). 'The influence of religion on attitudes towards the advertising of controversial products.' European Journal of Marketing 38(5/6), pp. 537-555.

Hair, J.F., Black, W.C., Babin, B.J. \& Anderson, R.E. (2010).Multivariate Data Analysis.Upper Saddle River: NJ Prentice Hall.

Hirschman, E.C. (1981). 'American Jewish ethnicity: Its relationship to some selected aspects of consumer behavior.' Journal of Marketing 45(3), pp. 102-110.

Jin, B. \& Kim, J.O. (2003).'A typology of Korean discount shoppers: shopping motives, store attributes, and outcomes.' International Journal of Service Industry Management 14(4), pp. 396-419.

Kahle, L.R., Kau, A., Tambyah, S., Tan, S. and Jung, K. (2005). 'Religion, religiosity, and values: implications for consumer behavior.' In Proceedings of the La Londe Seminar, 32nd International Research Seminar in Marketing (pp. 249-259) .La Londe-les-Maures, France: Sage.

Khraim, H.S., Khraim, A.S., Al-Kaidah, F.M. \& Al-Qurashi, D. (2011). 'Jordanian Consumer's Evaluation of Retail Store Attributes: The Influence of Consumer Religiosity. International Journal of Marketing Studies 3(4), pp. 105-116.

King, J.E. \&Crowther, M.R. (2004). 'The measurement of religiosity and spirituality: Examples and issues from psychology.' Journal of Organizational Change Management 17(1), pp. 83-101.

Lindridge, A. (2005). 'Religiosity and the construction of a culturalconsumption identity.' Journal of Consumer Marketing 22(3), pp. 142151.

Lumpkin, J.R. (1985). 'Shopping orientation segmentation of the elderly consumer.' Journal of the Academy of Marketing Science 13(2), pp. 272-289.

McDaniel, S.W. \& Burnett, J.J. (1990). 'Consumer religiosity and retail store evaluative criteria.' Journal of the Academy of Marketing Science 18(2), pp. 101-112. 
Mokhlis, S. (2006). 'The effect of religiosity on shopping orientation: an exploratory study in Malaysia.' Journal of American Academy of Business 9 (1), pp. 64-74.

-. (2008). 'Consumer Religiosity and the Importance of Store Attributes.' The Journal of Human Resources and Adult Learning 4 (2), pp. 122133.

Moschis, G.P. \& Ong, F.S. (2011). 'Religiosity and consumer behavior of older adults: A study of subcultural influences in Malaysia.' Journal of Consumer Behavior 10(1), pp. 8-17.

Muhamad, N. \&Mizerski, D. (2010). 'The constructs mediating religions' influence on buyers and consumers.' Journal of Islamic Marketing 1 (2), pp. 124-135.

Paulins, V.A. \& Geistfeld, L.V. (2003). 'The effect of consumer perceptions of store attributes on apparel store preference.' Journal of Fashion Marketing and Management 7(4), pp. 371-385.

Schroeder, J.E. (2000). The consumer in society: Utopian visions revisited. Marketing Intelligence \& Planning18(6/7), 381-387.

Schwartz, S.H. \& Huismans, S. (1995). Value priorities and religiosity in four western religions.Social Psychology Quarterly58(2),88-107.

Seock, Y.K. \& Lin, C. (2011). 'Cultural influence on loyalty tendency and evaluation of retail store attributes: An analysis of Taiwanese and American consumers.' International Journal of Retail \& Distribution Management 39(2), pp. 94-113.

Seock, Y.K. \& Sauls, N. (2008). 'Hispanic consumers' shopping orientation and apparel retail store evaluation criteria: An analysis of age and gender differences.' Journal of Fashion Marketing and Management 12(4), pp. 469-486.

Shachar, R., Erdem, T., Cutright, K.M. \& Fitzsimons, G.J. (2011). 'Brands: The opiate of the nonreligious masses?' Marketing Science 30(1), pp. 92-110.

Shaw, D.S. \& Clarke, I. (1998). 'Culture, consumption and choice: towards a conceptual relationship.' Journal of Consumer Studies \& Home Economics 22(3), pp. 163-168.

Sherman, E., Mathur, A. \& Smith, R.B. (1997). 'Store environment and consumer purchase behavior: mediating role of consumer emotions.' Psychology \& Marketing 14(4), pp. 361-378.

Sheth, J. N. (1981). An Integrative Theory of Patronage Preference and Behavior, College of Commerce and Business Administration, Bureau of Economic and Business Research, University of Illinois, UrbanaChampaign, pp.9-28. 
Shim, S. \& Kotsiopulos, A. (1992). 'Patronage behavior of apparel shopping: Part I. Shopping orientations, store attributes, information sources, and personal characteristics.' Clothing and Textiles Research Journal 10(2), pp. 48-57.

Sirgy, M.J., Grewal, D. \& Mangleburg, T. (2000). 'Retail environment, self-congruity, and retail patronage: an integrative model and a research agenda.' Journal of Business Research 49(2), pp. 127-138.

Sood, J. \& Nasu, Y. (1995). 'Religiosity and nationality: An exploratory study of their effect on consumer behavior in Japan and the United States.' Journal of Business Research 34(1), pp. 1-9.

Swimberghe, K., Flurry, L.A. \& Parker, J.M. (2011). 'Consumer religiosity: Consequences for consumer activism in the United States.' Journal of Business Ethics 103(3), pp. 453-467.

Swimberghe, K., Sharma, D. \& Flurry, L. (2009). 'An exploratory investigation of the consumer religious commitment and its influence on store loyalty and consumer complaint intentions.' Journal of Consumer Marketing 26(5), pp. 340-347.

Swinyard, W.R., Kau, A.K. \& Phua, H.Y. (2001). 'Happiness, materialism, and religious experience in the U.S. and Singapore.' Journal of Happiness Studies 2(1), pp. 13-32.

The Stone Agency (2012). 'Christian consumer segment ready to switch to compatible brands.' Available at http:/www.thestoneagency.com/wpcontent/uploads/Christian-Consumers-Willing-to-Switch-Brands.pdf (accessed 2012 July 26).

US Census (2012). 'Self-described religious identification of adult population.' Available at http://www.census.gov/compendia/statab/cats/population/religion.html (accessed 2012 July 27).

Vitell, S.J. \& Paolillo, J.G. (2003). 'Consumer ethics: The role of religiosity.' Journal of Business Ethics 46(2), pp. 151-162.

Wiebe, K.F. \& Fleck, J.R. (1980). 'Personality correlates of intrinsic, extrinsic, and nonreligious orientations'. The Journal of Psychology 105(2), pp. 181-187.

Wilkes, R.E., Burnett, J.J. \& Howell, R.D. (1986). 'On the meaning and measurement of religiosity in consumer research'. Journal of the Academy of Marketing Science 14(1), pp. 47-56.

Worthington, E.L. (1988). 'Understanding the values of religious clients: A model and its application to counseling.' Journal of Counseling Psychology 35(2), pp. 166-174.

Worthington, E.L., Wade, N.G., Hight, T.L., Ripley, J.S., McCullough, M.E., Berry, J.W., \& O'Connor, L. (2003). The Religious Commitment 
Inventory-10: Development, refinement, and validation of a brief scale for research and counseling.' Journal of Counseling Psychology 50(1), pp. 84-96. 